Western University

Scholarship@Western

Human Environments Analysis Lab (HEAL)

$1-2016$

A comparative analysis of place branding in Michigan and Ontario

Richard Sadler

Evan P. Cleave

Godwin Arku

Jason A. Gilliland

Follow this and additional works at: https://ir.lib.uwo.ca/healpub 


\title{
A comparative analysis of place branding in Michigan and Ontario
}

\author{
Richard Sadler, Evan Cleave, Godwin Arku \& Jason Gilliland
}

To cite this article: Richard Sadler, Evan Cleave, Godwin Arku \& Jason Gilliland (2016) A comparative analysis of place branding in Michigan and Ontario, Urban Research \& Practice, 9:1, 16-36, DOI: 10.1080/17535069.2015.1037341

To link to this article: https://doi.org/10.1080/17535069.2015.1037341

曲 Published online: 24 Apr 2015.

Submit your article to this journal $₫$

Џ Article views: 423

Q View related articles $\asymp$

View Crossmark data \lceil

4 Citing articles: 8 View citing articles 


\title{
A comparative analysis of place branding in Michigan and Ontario
}

\author{
Richard Sadler, Evan Cleave, Godwin Arku* and Jason Gilliland \\ Department of Geography, The University of Western Ontario, London, Ontario N6A 5C2, Canada
}

\begin{abstract}
Place branding has increasingly been adopted as a municipal initiative to change the trajectory of local economic development. Specifically, local municipalities and communities have used place branding not only as a response to the influence of globalization and neo-liberalism, but also economic challenges and restructuring. Like any other initiative, the ultimate goal is to enhance the economic and social well-being of local jurisdictions. Although a popular strategy, it is not clear if and how locally specific factors mediate the process. By comparing two cross-border geographical areas, this study attempts to identify how regional variability in the manifestation of politicaleconomic forces, as well as geographical influences, affects the use of place branding at local scales. Every municipality in Michigan $(n=1774)$ and Ontario $(n=414)$ was systematically examined for the presence and message of local place brands as presented through logos and slogans. The comparative analysis demonstrated that Ontario's municipalities utilized place branding to a greater extent, and that the dominant messages differ by region. Further, this analysis shows that - beyond political differences - geographical context appears to have an effect on both local place branding usage and message.
\end{abstract}

Keywords: place branding; economic development; municipalities; Michigan; Ontario

\section{Introduction}

In response to growing global competitive pressures and ongoing economic challenges, municipalities within advanced economies are increasingly adopting a wide range of approaches to highlight their unique attributes to improve local economic prosperity (Khirfan and Momani 2013; Pasquinelli 2013; Turok 2009). Of the range of approaches being pursued, one that aims to market the unique attributes of municipalities is the concept of place branding. Place branding has been closely linked with the concepts of place marketing and promotion. While the three are inter-related concepts, the latter two are concerned more with creating awareness of a place's existence and the assets it has. Although branding is also concerned with promotion and marketing of a place, it is also more contingent as it also concerned with developing the underlying strengths, ideas, and values that together comprise the place marketing message. Place branding, therefore, endows a municipality with a specific and distinctive identity and reputation that could not be achieved solely through existing tangible or functional assets (e.g. tourism opportunities; workforce size and training; taxes; municipal infrastructure). Instead, an identity or reputation emerges from perceived 'values' and 'intangible' factors (Cova 1996; Hanna and Rowley 2013). Typically, this brand identity is presented within a representational form such as a logo, slogan, or symbol. The identity presented in the graphic design, therefore, can be viewed as a condensed representation of the larger and more complex

*Corresponding author. Email: garku@uwo.ca 
local identity of a municipality. As a result, the logo or slogan of a municipality can be 'read' to gain insight into the fundamental essence of the locale.

Given its place in modern political-economies, and spurred by parallel forces of globalization and institutional restructuring at municipal, national, and international scales, place branding is considered a response to globalization, neo-liberalism, and economic challenges (Kavaratzis 2009; Pasquinelli 2013). At the local level, the utility of place branding has been emphasized within the rise of the entrepreneurial municipality, where local governance has taken a more businesslike approach with emphasis on profit motivation, innovation, and promotion (Greenberg 2008; Kavaratzis 2009; Pasquinelli 2013).

While place branding developed as a topic of general interest within the larger issues of political-economic neo-liberalism and local entrepreneurial governance, the field of place branding as an academic research topic has gained traction only in the last decade and a half (Gertner 2011; Lucarelli and Berg 2011). Despite the growing body of research, the current scholarship has two key limitations. First, there is a lack of evaluative or comparative studies with testable research hypotheses or models; and second, much of the existing research has focused primarily on a small number of case studies, mainly of large urban and former industrial locations that are perceived to be exceptional in their experience (see Hansen 2010; Kim 2010; Martínez 2007). These single-site case studies focus on explaining the process of aligning stakeholders or marketing of brands (Kavaratzis 2009), identifying specific municipal assets and messages that are incorporated into the brand (Giovanardi 2012; Kim 2010), and attempting to measure brand success (Niedomysl 2004, 2007). Thus, a critique of existing place branding literature is that it is difficult to identify and draw conclusions on commonalities or divergences in the underlying factors that influence place branding. Consequently, place branding is generally examined and explained as a ubiquitous and homogenous process of globalization, neo-liberalization, and entrepreneurialism.

To determine how the variability in political and institutional forces manifest themselves at the local level and influence economic development policy decisions, this paper undertakes a comprehensive comparative analysis of place branding usage at the municipal level in the State of Michigan (USA) and the Province of Ontario (Canada). This choice of study areas allows for the comparison of place branding across two large regions and over 2000 municipalities, each with differing geographical, political, economic, and institutional contexts. The aims of this research are

(1) To determine whether geography and/or institutional context affects the usage of place branding and the message communicated.

(2) To determine whether place branding usage is ubiquitous at the municipal level.

(3) To determine whether place branding messages are homogeneous across municipalities within a region.

To the best of our knowledge, no studies have attempted to identify and compare the patterns of place branding amongst municipalities in neighbouring, cross-border regions. One question arising from this concern is: do neighbouring municipalities follow geographical trends and contribute to a homogenization of branding? If so, there should be similarity in the branding outcomes across space, such as similar usage levels among similar types of municipalities.

Generally, place branding initiatives appeared to be embedded within local governance, which is variable across political boundaries due to differing manifestations of 
political economic forces. As a result, we do not expect to uncover the presumed ubiquity and homogeneity of the process. Against this background, the hypothesis guiding the current research instead argues that place branding is neither universally homogenous nor ubiquitous. This hypothesis suggests that variation will be observed between municipalities in Michigan and Ontario. Additionally, we expect institutional context, rather than geography, to be the underlying influence of place branding usage, while geographic influences (social, economic, and physical) will guide message content. To test these hypotheses, both inferential and spatially based analysis will be utilized to consider the differences between municipal place branding in Michigan and Ontario.

This paper, therefore, contributes to an understanding of the underlying complexities of place branding: it investigates how its use and content vary across space through a robust, testable, comparative approach; and it provides insight into place branding in a geographical region that has been previously under-investigated. Furthermore, there have been no spatial-geographic information system (GIS) or comparative-statistical investigations in North America or globally to date that investigate the phenomena of place branding in two large, neighbouring political regions. As a result, this paper contributes a unique perspective and investigative approach to the discourse on place branding.

\section{A review of place branding}

\section{What is place branding?}

Branding is a technique traditionally associated with companies: the values and advantages of the company and product are distilled into a handful of qualities and imparted onto a name, design, symbol, or message to distinguish and promote the products of a company (Khirfan and Momani 2013). When distilled to a semiotic construct, a brand becomes 'a strategically produced and disseminated commercial sign (or a set of signs) that is referring to the value universe of a commodity' (Askegaard 2006, 91). The desired outcome of the branding process, therefore, is the development and strengthening of a relationship or connection between a company's product and the emotional perception of the consumer (Hislop 2001).

Place branding at the municipal level functions in much the same way. A municipality's brand is a condensed message that evokes the values associated with the city (Avraham 2004), associates the brand with certain values (Dinnie 2011), and thus conjures psychological and social connotative meanings (Danesi 2006). Municipalities emphasize the unique and dynamic aspects to present 'the distinctive municipality' (e.g. Martínez 2007) or to portray unique image and place identity. In this regard, the application of place branding is an expression of the interests of a particular group or groups, and can be contextualized as a political act intended to produce particular outcomes (Eshuis and Edwards 2012). In its basic form, therefore, all place branding can be considered an effort to improve local economic development efforts.

The broader purpose of a brand is to create engagement on the part of the consumer. The perception of a place formed by potential customers (individuals, tourists, and investors) prior to consumption of the place is of critical importance within the branding process (Hanna and Rowley 2013). Similar to consumer products and services, formulating predisposition and intent to buy is one of the central drivers of brand investment and decision-making (Allen 2007; Hanna and Rowley 2013). The goal is to create a proposition that compels the customer to buy into the ideas being presented. The branding of municipalities thus aims to create a favourable image of the place by emphasizing certain 
functional, symbolic, and experiential aspects, while the place brand itself is a symbol that suggests ways of experiencing or relating to the municipality (Eshuis and Edwards 2012; Hansen 2010; Johansson 2012).

\section{Political-economic underpinnings of place branding}

The rationale for place branding often draws on a discourse of a competitive, globalized world where places are primarily constituted as settings for symbolic consumption (Zukin 1989) whereby they become sites of symbolism and experience (Marling, Jensen, and Kiib 2009). In fact, municipal branding is typically interpreted from the context of globalization, as a 'market-led' approach to stimulating local economic development (Cleave and Arku 2014; Greenberg 2008; Pasquinelli 2013). Branding has become an empirical phenomenon within the governance of urban jurisdiction and municipalities, particularly as a policy strategy for urban regeneration and redevelopment (Eshuis and Edwards 2012; Johansson 2012; Harvey and Young 2012). Eshuis and Edwards (2012) further suggest a link between place branding and urban governance, following the rationale that a place first decides what kind of brand it wants to become and then enhances developments to support that brand.

The adoption of place branding within urban governance at the municipal level is also linked with structural changes to local and global political-economic institutions through structuring economic changes and neo-liberalization (Greenberg 2008; Hackworth 2007; Pasquinelli 2013; Peck 2002; Wolfson and Frisken 2000). The decline of a Fordist-structured global economy in the 1970s and 1980s facilitated changes to economies on all scales (Harvey 1989, 2007; Peck 2002). The regions in which our study takes place - Michigan and Ontario - were strongly affected by this economic restructuring and neo-liberal policymaking, as formerly prosperous municipalities with large manufacturing complexes dealt with the aftermath of deindustrialization (Wolfe and Gertler 2001).

This period is characterized by the nation state declining as the primary unit of competition (Giovanardi 2012) and the social and spatial restructuring of cities and other contemporary urban centres as the sites of capital accumulation (Brenner and Theodore 2002; Peck 2002). Concurrently, the realities of globalization forced urban centres to push their competitiveness and fully engage in the politics of resource attraction. At the urban level, the effects of globalization and neo-liberalism manifest themselves in the policymaking and approach to urban governance (Addie 2008; Gillen 2009; Turok 2009). Based on a free-market ideology, these programmes propose a decrease in state regulation and the introduction of private sector strategies (Cleave and Arku 2014; Rantisi and Leslie 2006). An additional urban crisis was created from the combination of the new economic reality of globalization and the neo-liberal downloading of responsibility from the state: 'in the late 1980s and early 1990s, a fiscal crisis in cities across Europe and North America caused by the triple problems of de-industrialization, a falling tax base and declining public expenditure had some serious implications for cities' (Hannigan 2003, 353). Factories were closing and jobs disappearing as the industrial culture on which the economy was built began to erode. Concurrently, the pursuit of neoliberal policy allowed the emergence of political-economic structures and ideologies based around privatization and deregulation (Rantisi and Leslie 2006). Viewed as the precursor to the terminal decline of traditional urban economies, a need existed for economic restructuring which 'stimulated the search for new roles for cities and new ways of managing their problems' (Barke 1999, 486). 
To combat this foreseen decline, approaches to governance altered from a managerial style to aggressive and businesslike practice (Hannigan 2003; Harvey 1989). This was primarily due to the rapidly changing urban political-economies found within North America and Europe characterized by the emergence of a new 'entrepreneurial' style of local governance: urban centres were promoted as sites for accumulation (Brenner and Theodore 2002). This entrepreneurialism captured the businesslike essence of city governance and its associated characteristics, including risk-taking, inventiveness, and profit motivation (Harvey 1989, 2007; Hubbard and Hall 1998). Consequently, image promotion was increasingly privileged by planners, economic development practitioners, and politicians (Hannigan 2003; Harvey 1989). The use of branding within this entrepreneurial governance can be viewed as a natural outcome of the emerging system, as it presented a new (and therefore risky) means of allowing urban areas to remain economically relevant through inventive repackaging and promotion (Pasquinelli 2013).

A final consideration within the research domain is that underlying urban economic issues have been drivers of place branding, leading to brand convergence and homogenization. There is an assumption that the adoption of place branding by municipalities is simply a response to trends elsewhere (Barke and Harrop 1994), and that towns and cities are adopting the practice because of "fears of local policy makers that by failing to "play the game" they will become losers in the global economy' (Millington, Young, and Lever 1997, 19). The replication of successful economic development strategies (see Reese and Sands 2007) leads to a rising lack of distinctiveness in the messages that municipalities promote. The homogenization of physical assets within urban environments and the development of 'clone towns' have further been suggested as primary drivers of contemporary place branding (Eisenschitz 2010; Turok 2009).

\section{An overview of Michigan and Ontario}

Michigan and Ontario make for natural comparison cases for several reasons: (1) their spatial proximity and thus greater likelihood of diffusion of policy information; (2) the long shared history of industrial and manufacturing activities (Reese 1992a, 1992b, 1993); (3) a history of convergent economic and land development policies (Reese and Sands 2007); and (4) similar populations and populated areas (Jacobs 2009). Additionally, some economic development research has compared cities in Michigan and Ontario to understand how institutional contexts may influence business practices (Sadler, Clark, and Gilliland 2013).

These similarities coexist with several distinctions between the two places. For instance, economic development is far more likely to be held in a separate department or organization in Ontario. Government restrictions on financial incentives are far less common in Michigan (Reese and Sands 2007). As well, 'inherent institutional variations have made Canadian provinces much more involved in local government activities than ... most American states ...This has distinctly affected their respective cities' (Jacobs 2009, 352).

Additionally, several existing studies showed a divergent path in several domains (e.g. see Jacobs 2009). In Michigan, urbanization is dominated by intense interracial relations, state laws promoting municipal fragmentation, policies supporting fierce inter-local competition and tax abatement, and a vulnerability of cities due to the historical concentration of employment in the auto industry (Jacobs 2009; Reese and Sands 2007). In Ontario, meanwhile, a racial-ethnic mosaic has fostered calmer race relations, provincial policies tend to support subregional planning, restrictions are placed on local authority, municipal 
tax abatements are prohibited, and the employment base in cities has remained more diverse. Jacobs refers to the competitive atmosphere in Michigan as 'municipal Darwinism' (2009, 359).

Of additional interest to this study is the much larger number of local governments in Michigan (with relatively smaller populations). Despite being of similar population and 'less than one-sixth of Ontario's size in land area (56,804 to 354,500 square miles), Michigan has four times as many municipalities (1,776 to 414)' (Jacobs 2009, 362).

In both Michigan and Ontario, municipalities have been affected by the ongoing global economic crisis precipitated in 2008, as manifest through manufacturing plant closures, flight of corporate head offices, and rising unemployment and poverty levels (Arku 2014). These challenges have affected the economic fortunes of most municipalities in Michigan and Ontario and their approaches to local economic development (Hutton 2010; Reese 2010; Reese and Sands 2007). To cope with these issues, municipalities have been forced to become proactive in their economic development efforts.

\section{Ontario}

Within the province, a tension exists between the neo-liberalization of global economic markets and the institutional controls at the provincial level that constrain them. Despite the continual downloading of economic responsibilities from the province to its municipalities, local governments remain constrained by the province's restrictive legislation that limits the extent of their power and economic development efforts (Arku 2014; Gertler 1990; Reese and Sands 2007). Gertler (1990, 43) argued that:

such restrictive provincial statutes have important implications for the manner in which local governments fashion and pursue their own economic development strategies, since they are constrained from engaging fully in the kind of competitive inter-jurisdictional bidding for economic activity that American municipalities have developed.

Municipalities in Ontario have thus been compelled to find creative ways to enhance the economic growth and competitiveness of their jurisdiction, particularly as American states have taken a more liberal, free-market approach to local economic development. And because of the need for creative development strategies, place branding has been increasingly emphasized to positively promote the municipalities to draw in tourists, talent, and business.

\section{Michigan}

In recent years, Michigan's state government has pursued a series of market-oriented programmes to help grow the economy. The orientation towards business suggests great potential for municipalities to emulate business practices and make use of place branding.

Michigan has a long history of home rule government, which has strengthened the notion of local control in planning decisions. As well, the state levies few mandates, incentives, or resources for regional planning, making intergovernmental collaboration historically less common (Gerber and Loh 2010; Reese and Malmer 1994). Local government consolidation has also been virtually non-existent, especially since the implementation of home rule granting 'charter' township laws in the 1950s and 1960s. Michigan therefore exhibits severe municipal fragmentation. As recounted by Gerber and Loh (2010), 'The strength and fragmentation of local governments in the US provide 
strong evidence for Tiebout's hypothesis of a "market" for localities, where individuals choose among communities with different levels of service provision' (Tiebout 1956, 2304).

\section{Data collection}

The decision-making process of the images and symbols chosen to represent a community's brand provides insight into the motivations behind the branding process (Johansson 2012; Khirfan and Momani 2013). The place brand images promoted by a municipality can therefore be read and analysed through semiotics to understand associated meanings. Furthermore, the spatial clustering of economic development activities between municipalities can be understood as an emulation of perceived preferable traits to attract investment. This study draws on the semiotic relationships present in the visual identities of urban centres in Michigan $(n=1774)$ and Ontario $(n=414)$ and their geographic relationship to one another to identify which areas of local economic development are privileged by their presence in brands. The visual elements were drawn from a systematic and comprehensive inventory of brand imagery present on municipal websites in Michigan and Ontario. Typically, local websites are the initial point of interface between municipalities and target audiences (Urban 2002), and existing municipal brands are likely to be incorporated and featured prominently in any online presence.

The content of websites was systematically examined and classified based on a series of guidelines developed prior to data collection. Hanna and Rowley's (2008) categories of primary place brand messages were expanded upon in this analysis to develop the classification scheme used to guide the semiotic analysis and classify the content of the web pages into the following broad categories: culture, industry, agriculture, tourismenvironment, tourism-recreation, heritage, and stylization (Table 1). Each of these categories covers a broad sector of the economy, and usage therefore implies a desired connection between the municipality and the audience that is interested or involved in that sector. The broad categories allowed all place branding messages encountered to be classified.

In this classification scheme, culture referred to a range of elements that encompass the cultural capital held within a municipality. These include both abstract ideas such as creativity, but also more tangible assets such as gastronomy and music associated with the locale. Industry was a loose term, referring to any industrial development, urban

Table 1. Guidelines for categorizing visual identity elements.

\begin{tabular}{|c|c|}
\hline Category & Key associated references \\
\hline Culture & $\begin{array}{l}\text { Gastronomy/food, sports, film, theatre, artwork, literature, music maple leafs, } \\
\text { creativity/creative class, leisure, spirit }\end{array}$ \\
\hline Industry & $\begin{array}{l}\text { Factories, modern buildings and cityscape, freight transport (rail and ship), tools, } \\
\text { natural resources, strength, perseverance, industry, business/business } \\
\text { relocation, the future, modernization, urban, natural resources, opportunity }\end{array}$ \\
\hline Agriculture & Farmland, farm equipment, barn yards, farm animals, growth, cultivation \\
\hline Tourism - nature & Natural environment - wildlife, plants, forest, river, lake; escape, nature \\
\hline $\begin{array}{l}\text { Tourism - } \\
\quad \text { recreation }\end{array}$ & Boating, adventure, hiking, discovery, exploration \\
\hline Heritage & $\begin{array}{l}\text { Historical buildings and cityscape, colonial era military, tall ships, history, past, } \\
\text { heritage, fatherland/motherland }\end{array}$ \\
\hline
\end{tabular}


cityscape, business, or general consideration of economic progress. Agriculture referred to visual cues suggesting farming or landscapes that are dominated by farmland. Heritage primarily considered the built environment, references to local history, and historic architecture. Tourism was divided into two categories - the natural environment and recreation - representing differing core tourism-based assets and activities. A final category - stylization - was included to capture abstract elements that had no specific symbolic representation. This category included logos that emphasized typographic designs and abstract shapes that could not be associated with another brand category.

To collect the data acquired through the semiotic analysis, a simple binary coding system was developed in which the brand categories present within each municipality's visual identity were recorded. In instances where a municipality's logo contained symbology consistent with multiple brand categories, all relevant categories were recorded. In instances where multiple symbolic elements referenced the same brand category, a value of 1 was assigned to the categories identified as present. In essence, the analysis of brand images was focused on the presence and not the importance or magnitude of the elements found within a logo.

\section{Data analysis}

The investigation conducted in this study to fulfil the research hypothesis can be broken into two research sub-questions:

\section{RQ1: Is there a difference in the rate of place branding usage at the municipal level in Michigan and Ontario? \\ RQ2: Is there a difference in the place branding messaging at the municipal level in Michigan and Ontario?}

These research questions were appraised through two methods: a comparative analysis relying on a $z$-test for proportions; and spatially, through a point density analysis.

\section{Comparative analysis}

To compare the rates of place branding within the two regions, we used a two sample $z$ test for difference of proportions. Guiding this set of tests between rate of place branding in Michigan $\left(p_{1}\right)$ and Ontario $\left(p_{2}\right)$ was the statistical hypothesis (at a significance of $\alpha=0.05)$ :

$\mathrm{H}_{0}$ : There is no difference in branding between regions $\left(p_{1}=p_{2}\right)$

$\mathrm{H}_{\mathrm{A}}$ : There is a difference in branding between regions $\left(p_{1} \neq p_{2}\right)$

The statistical comparison of place branding in Michigan and Ontario was completed two ways: first, a comparison of the overall rates of place branding; and second, a comparison of the frequency of each brand category. For each analysis, place branding was examined at an overall level, as well as in components defined by municipality type. Finally, the influence of population was examined by identifying the expected number of communities associated with each brand message category. This expected number of communities was developed based on the proportion of the total population in each region (Ontario and Michigan) that was associated with a particular brand message category. In 
instances where a municipality had only one brand category, the entire population was considered associated. In instances where municipalities promoted several categories in their message, the associated population was calculated as 'municipality population'/ 'number of brand categories present'. The calculated portion of the population for within each region that was associated with a particular brand category was used to determine the expected number of municipalities through the calculation: 'proportion of population associated with a particular brand message' multiplied by 'the total number of municipalities within the region'. As a result, the expected number of municipalities can be described as based on the proportion of the populations associated with each brand message in each region.

The place branding variables were drawn from the semiotic and content analysis, while the population and municipality types were drawn from the respective census of each region (2010 U.S. census; 2011 Canadian census). Municipalities are defined differently in Michigan and Ontario, thus the municipalities were reclassified into core (Michigan $n=416$ : comprising cities and charter townships; Ontario $n=139$ : cities and towns) and periphery (Michigan $n=1358$ : townships and villages; Ontario $n=274$ : townships, municipalities, and villages). Core municipalities are assumed to have more active local governments and greater responsibilities for a range of municipal services and developments, including a primary and active responsibility in stimulating local economic growth.

\section{GIS visualization and point density analysis}

The proximity and general environmental similarities between Michigan and Ontario also present an interesting opportunity to determine whether place brands show spatial patterns either cross-border or within each region. This relationship may be examined in many ways with GIS mapping software; we present two perspectives in this paper.

First, we mapped the prevailing place brands onto the polygon corresponding to the geographical boundaries of each municipality. We then converted the municipal boundary polygons into points, weighted the points by the population, and conducted point density analysis for each of the seven place brand categories. This process yielded a series of raster (continuous) surfaces.

Mapping these surfaces individually shows the spread of individual place brands in space accounting for variations in population density. In weighting by population, however, we privilege more densely populated areas. Still, this is more useful than an unweighted visualization because a simple mapping of place brands by municipality may visually over-represent the place brands of geographically large, rural municipalities with small populations.

Second, we calculated the population-weighted point density of individual place brands to determine the most common place brand at any specific location within the entire Michigan-Ontario region. This was derived by taking the 'maximum' value for every single pixel in the raster series to determine the most prominent place brand category in every location. We limited the point density analysis to incorporated areas, thus explaining the gaps in northern Ontario.

The relative advantage of conducting a raster analysis of the dominant place brand is that it presents a nearly complete surface of brand identity even where some municipalities have not adopted a brand. Thus, it might suggest the type of branding that would occur in these municipalities. As well, both of these analyses are helpful in visualizing geographically what may otherwise be viewed as a political-economic issue; that is, we 
can conceptualize minor geographic variations and determine whether certain place brands are more popular, for instance, in the northern or rural regions of both Michigan and Ontario.

\section{Results}

\section{Comparative analysis}

The comparison of both the rate of place branding and the messages communicated illuminates several significant differences in municipality-level place branding strategies in Michigan and Ontario. We identified that municipalities in Ontario use branding at a much greater rate when compared to their Michigan contemporaries. Regardless of how municipalities are categorized, the difference in place branding usage remains consistent. As such, the pattern is observed beyond the overall level, as municipality-type and population-based comparisons also identify more frequent place branding usage in Ontario municipalities. Specifically, $88 \%$ of Ontario's municipalities were observed to promote some form of brand imagery through a logo or slogan, while only $48 \%$ of Michigan municipalities did so (see Table 2). The results of the $z$-test comparing the observed rates of municipal branding in each region produced a value of $z=14.9$, exceeding the critical value of 1.96 which suggests significance. The $z$-test, therefore, rejected the null hypothesis $\left(p_{1}=p_{2}\right)$, indicating that the increased rate of place branding in Ontario compared to Michigan is statistically significant.

As noted, more frequent observations of place brands in Ontario's municipalities were identified regardless of how municipalities were categorized. The pattern, therefore, was found to be significant when municipalities were compared by type (see Table 2): both core and periphery municipalities in Ontario (core $=91 \%$; periphery $=87 \%$ ) used place branding considerably more frequently than their Michigan counterparts (core $=60 \%$; periphery $=44 \%$ ). Corresponding $z$-test scores indicate significance between Ontario and Michigan subgroups for core and periphery $(z=6.90$ for the core; $z=12.91$ for the periphery). In Ontario, villages were the municipality type least likely to use place branding, at $63 \%$. Meanwhile, in Michigan the highest usage rates were lower than this, with cities at $60 \%$ and charter townships at $58 \%$. The smallest and least developed municipalities in Ontario, therefore, use place branding at a higher rate than the highest levels of urban centres in Michigan.

Finally, when the population-weighted indices for Michigan and Ontario are compared, the trend occurs again (Table 2). Indeed, the weighted index suggests that Ontario municipalities will use place branding at a rate of $97.5 \%$, with Michigan municipalities lagging behind (61\%). From this, two conclusions can be drawn. First, Ontario municipalities being significantly more likely to use place branding, which is supported by the result of the $z$-test $(z=14.41)$ which rejects the null hypothesis. Second, the weighted results suggest that place branding is occurring consistently across municipalities of all sizes in Ontario. Even in the smallest municipalities (population less than 2000) where place branding is observed to be used the least frequently a visual identity was still identified $78 \%$ of the time. This rate was higher than the total rate of usage in Michigan (48\%). Indeed, place branding was found to be used in Ontario's smallest municipalities more frequently than in Michigan's largest $(73 \%$ in municipalities with a population above 75,000).

Based on these results, the null hypothesis for each set of comparisons is rejected. RQ1 can therefore be satisfied with the answer that there is a difference between Michigan 


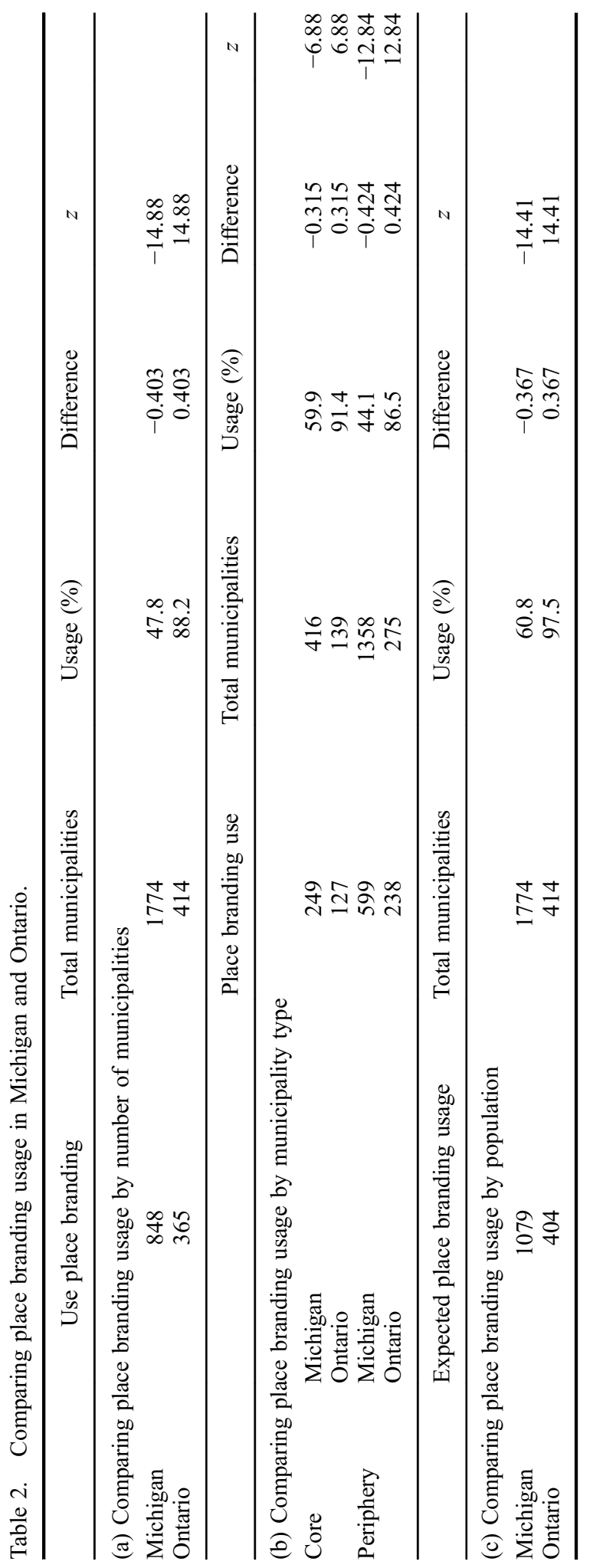


and Ontario in the rate of place branding occurring. As a result, based on the three measures of comparison, it can be concluded that place branding is being systemically adopted more frequently across all forms of municipalities in Ontario.

While RQ1 considered the rates of branding, RQ2 compares municipalities in the two regions to identify if their messaging varies. There were seven brand messaging dimensions (see Table 1) that were compared in this analysis. We found that Michigan's municipalities were more likely to promote culture (observed in 20.3\% of Michigan's communities as compared to $8.3 \%$ in Ontario) and industry (16.9\% to $12.6 \%)$. Alternatively, Ontario's municipalities privileged agriculture $(14.7 \%$ to $6.9 \%)$, heritage $(12.8 \%$ to $9.3 \%)$, and recreation $(12.1 \%$ to $9.3 \%)$. Finally, two categories - nature $(33.5 \%)$ and stylization (at approximately 6\%) - were used equally among municipalities in both regions.

The differences in the rates in which the brand messages promoted were found to be statistically significant between the two regions. At an overall level, there were five categories where the incorporation into brand messaging differed at a level that rejected the null hypothesis (Table 3). As noted, Michigan municipalities were found to emphasize culture $(z=6.67)$ and industry $(z=2.42)$ more often than those in Ontario. Alternatively, the Ontario municipalities incorporated agriculture $(z=5.52)$, recreation $(z=3.29)$, and heritage $(z=2.33)$ more frequently than their American counterpart. Interestingly, when the brand messaging is considered by weighted population, there is a reversal (Table 3), where Ontario municipalities incorporate industry more frequently $(29.4 \%$ to $12.3 \% ; z=8.61)$ and alternatively Michigan municipalities incorporate heritage $(6.7 \%$ to $4.2 \% ; z=1.92)$. Further, nature tourism is significant in this stage of comparison $(31.1 \%$ to $25.7 \% ; z=2.16)$, indicating that Michigan municipalities are adopting it more frequently into their visual imagery. These results suggest that Ontario's largest urban centres are emphasizing industry in their brand messaging, while in Michigan this message is being observed in smaller locales. Alternatively, Michigan's larger municipalities appear to be privileging heritage and nature tourism in their promotional efforts.

When compared by municipalities type (Table 3), Michigan municipalities in the core $(25.6 \%$ to $7.3 \% ; z=5.21)$ and periphery $(18 \%$ to $8.8 \% ; z=4.41)$ again emphasize culture more often than similar urban areas in Ontario. Other notable variations between the two regions are that Ontario's periphery emphasizes agriculture $(19 \%$ to $7 \% ; z=6.69)$ and recreational tourism $(13.6 \%$ to $7.4 \% ; z=3.66)$, while Michigan's periphery emphasizes industry $(16.6 \%$ to $12 \% ; z=2.19)$. In conjunction with the patterns observed when population's influence was examined, it appears that brands promoting industry are more centralized in Ontario's urban core, and are more dispersed in Michigan, occurring more in the peripheral regions.

Ultimately, the second stage of analysis (RQ2) demonstrates that there are significant differences in the way place branding manifests itself at the local level.

\section{GIS analysis}

We have shown significant differences in the rate and nature of place branding between Michigan and Ontario, but we also sought to understand whether these differences would yield starkly different spatial distributions of popular brand categories. Two geographical perspectives are presented which help visualize the spatial differences in place branding and suggest spatial patterns in place brand usage. First, Figure 1 shows a series of maps with the density of each specific place brand category weighted by population. Figure 2 , 


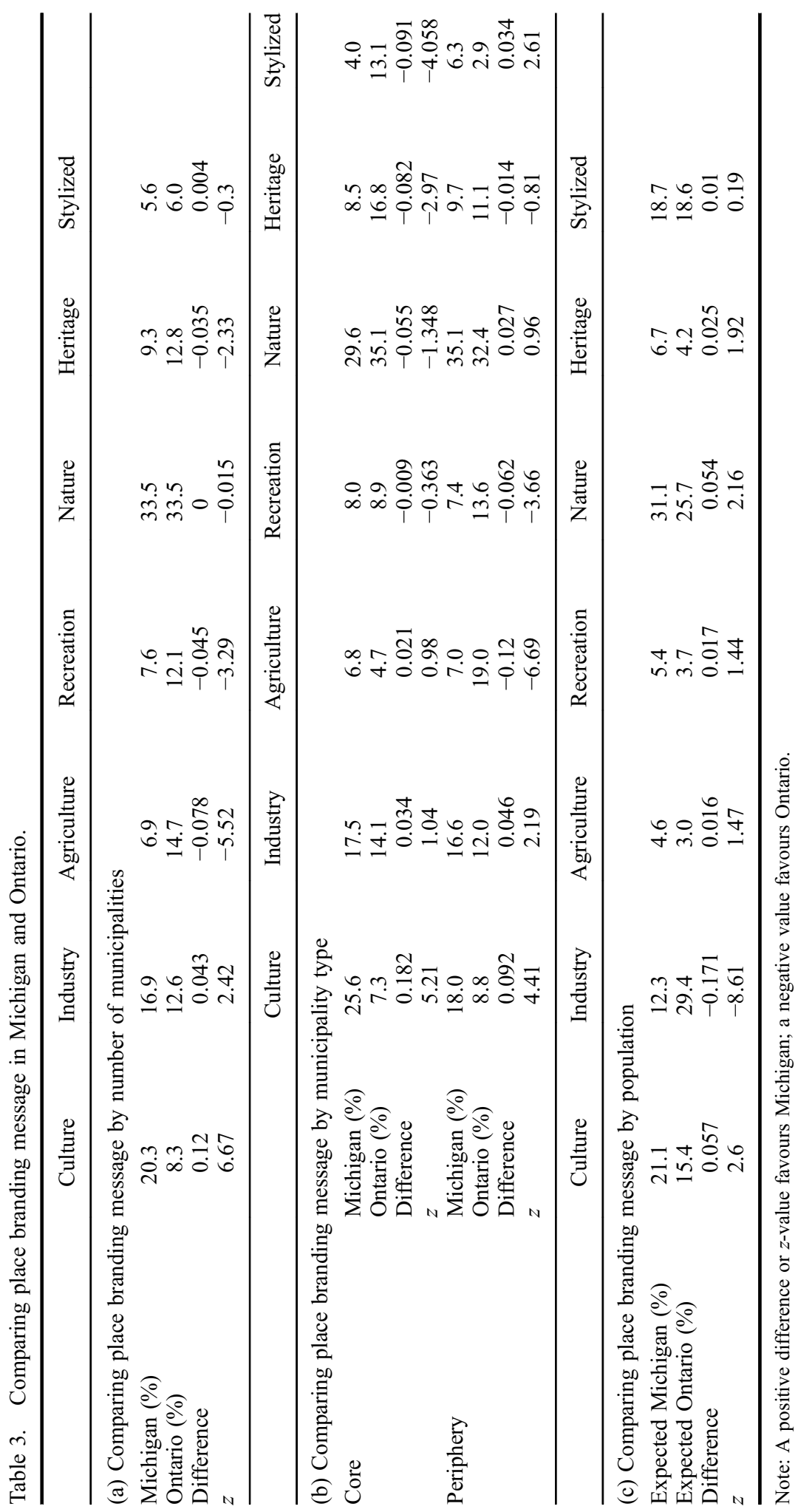



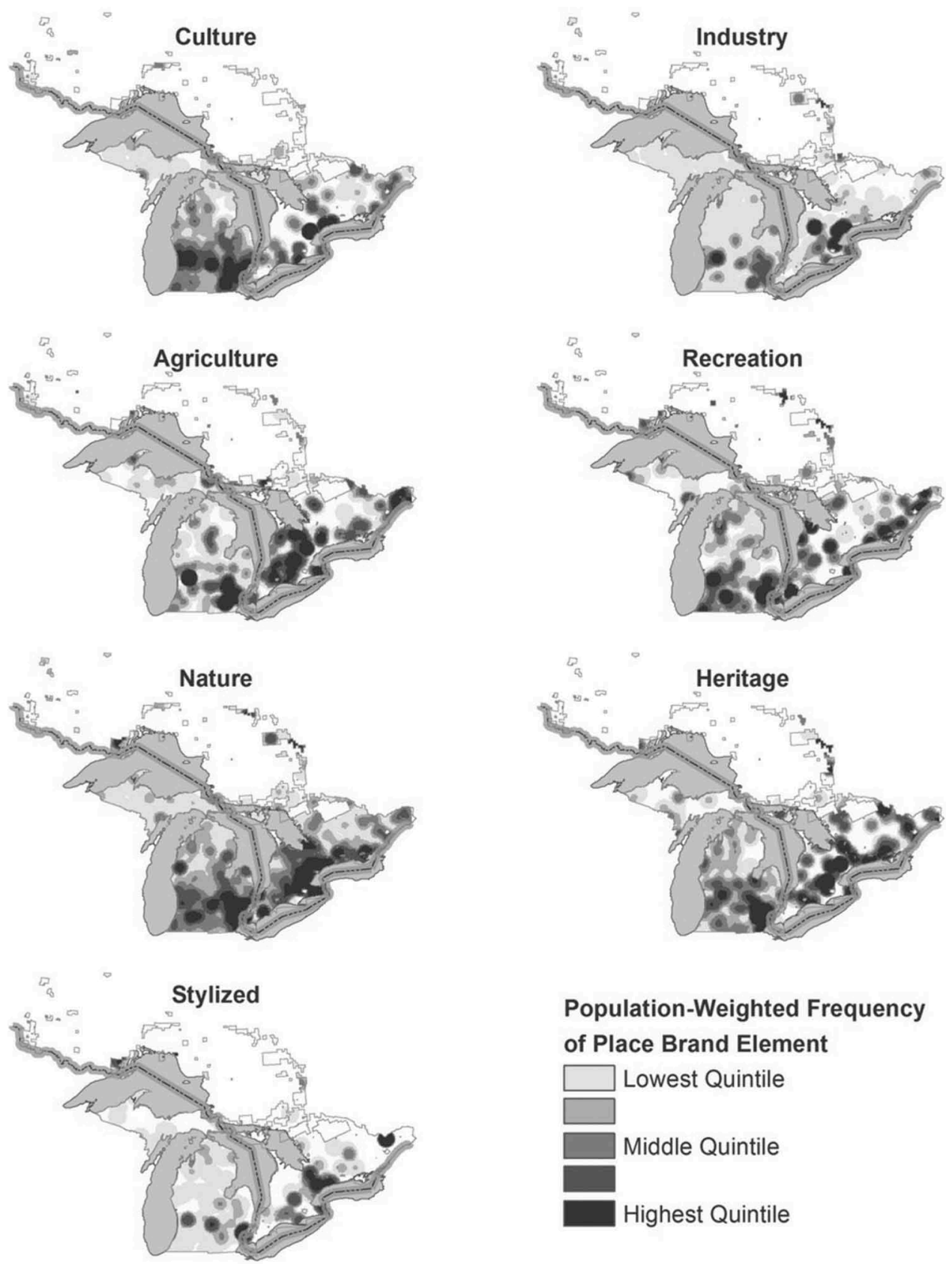

Figure 1. Population-weighted frequency of place brand element. Additional cartographic information on these maps is available in Figure 2.

meanwhile, shows the dominant place brand in space by taking the maximum place brand category score.

Building on the finding from Table 3 that Michigan municipalities used agriculture, recreation, and heritage brands less frequently than Ontario, noticeable gaps appear in 
Figure 1 in each of these categories. Most notable is the dominance of agriculture as a brand throughout southwestern Ontario compared to the agricultural area of MidMichigan. In support of the findings in Table 3, industry and nature are present virtually everywhere in Michigan and Ontario. The nature brand is especially notable in the Upper Peninsula of Michigan and northwest of Ottawa in Ontario as these areas are sparsely populated yet well represented by this brand. Considering the relatively lower population density in rural regions of both Michigan and Ontario, the recreation brand also tends to be well-represented outside of major population centres. Culture is much more diffuse throughout Michigan municipalities than it is in Ontario, where it is concentrated around the Greater Toronto Area.

When considering the most common brands by population-weighted point density analysis (Figure 2), the most geographically common category is nature. This category pervades as the most common even in some small- to medium-sized urban regions in both Michigan and Ontario, including Marquette, Traverse City, Saginaw, Flint, Kalamazoo, Port Huron (Michigan), Sarnia, Kitchener, Kingston, and St. Catharine's (Ontario). Culture tends to be more common in Michigan, with several concentrations throughout the centre of the state and in the Upper Peninsula, while it is only seen in small pockets along Lakes Erie and Huron. Recreation, meanwhile, is more common throughout smaller communities in Ontario, while only a few spots in the Upper Peninsula of Michigan exhibit this category as the most common. Industry is relatively common in both regions, though Ontario has a wider range of municipalities under this category, both geographically and in terms of size. The lack of a regular spatial pattern (either within region or cross-border) suggests that inter-municipality collaboration has not occurred with regard to this economic development activity.

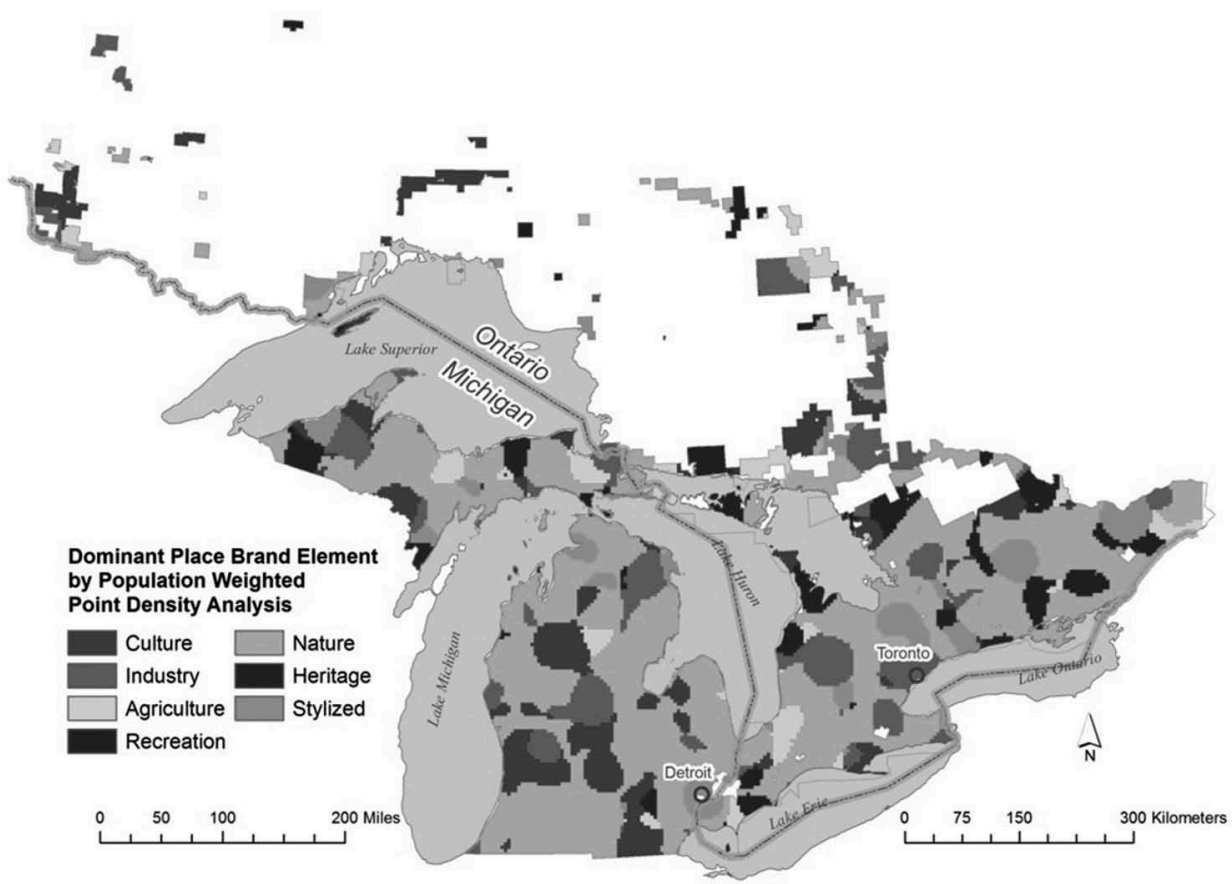

Figure 2. Dominant place brand element by population-weighted point density analysis. 
This mapping may be of particular value to municipalities (especially in Michigan) that have not yet adopted place branding but who are considering the practice. Examining the most popular existing place brand category (Figure 2) could enable a municipality in their decision-making. For example, a municipality in central Lower Michigan could follow the trend and adopt a culture-based place brand. Conversely, municipalities in southern Michigan could adopt a brand distinct from the nature brand so prevalent in the area.

As well, municipalities could examine the relative spread of all place brands (Figure 1) to determine least popular brand category in their area. For instance, despite the natural amenities available to municipalities in northwestern Lower Michigan, many other categories are more common than the recreation brand. Thus a municipality which employed a recreation-based place brand would be distinct from others nearby.

\section{Discussion}

Based on the outcomes of the three research questions, several conclusions can be drawn. First, municipalities in Ontario use place branding at a much higher rate than their contemporaries in Michigan. Coupled with the variation in the messages that are presented at the municipal level in both regions, we find that place branding is neither universally homogenous nor ubiquitous in either Michigan or Ontario. There are several potential political-institutional explanations for the discrepancies in the rates of place branding usage observed in Michigan and Ontario.

Because place branding is often integrated into local economic development policy, slight differences are created between Michigan and Ontario. Structurally, both regions have experienced similar economic trends, with decreased manufacturing and an emerging emphasis on service and knowledge-based economies. Ontario's economy, however, is transforming more quickly. This may be due to Ontario being a more expensive market for manufacturing firms to operate in, and to Ontario's primacy in the Canadian economy (which has helped economic development remain diverse). Reese and Sands (2007) also note that Ontario municipalities have two distinct policy differences compared to their Michigan contemporaries. First, the restrictive legislative controls by the provincial government have forced municipalities to forgo the generally ineffective approach of disseminating public funds to private interests through tax breaks and incentive bonuses (Leigh and Blakely 2013; Buss 2001; Reese and Sands 2007; Rubin and Rubin 1987). This approach to economic development has been found to be ineffective in facilitating the relocation and growth of small firms (Ladd 1994). Similarly, tax incentives have been identified as a minor contributor in the recruitment of larger industry, and only succeed in diminishing the financial resources available to local governments (Dewar 1998; Kolesar 1990).

Canadian municipalities, therefore, have been forced to market their infrastructural and asset base advantages to attract business and talent. Second, within the policy approaches of the two regions Michigan municipalities have traditionally adopted a more passive government role that relies on traditional financial and infrastructure incentives. Conversely, Ontario's municipalities have taken a more entrepreneurial approach and emphasized an active public sector with strong professional staffs. The entrepreneurial attitude of local governments in Ontario has led to greater goal-directed behaviour, while their Michigan counterparts appear more likely to use planning as a justification for a wider, less-focused array of development policies. 
In short, Ontario's municipalities are more strategic in their economic development, reflected by a focus in the selection of economic development policies and greater attempts to integrate local economies into the global economy to respond to globalization, such as through a greater interest in the development of export markets (see Arku 2014; Arku and Oosterbaan 2014; Reese 2014; Reese and Sands 2007). Further existing research showed that place promotion was more prevalent in Ontario, a result of institutional differences at the state/provincial level (see Reese and Sands 2007). The results of our study, however, expand on this finding and indicate that the same controls may be influencing higher rates of place branding initiatives.

In Ontario, although municipalities operate in a more regulated environment where social policy is strongly emphasized, they operate within an increasingly neo-liberal and market-oriented environment (Arku 2013). This is evident in the transfer of both administrative and financial responsibilities for local services from the provincial government to municipal governments. This transfer of responsibility may appear to be affecting the way and manner in which economic development tasks are being carried out. Wolfson and Frisken $(2000,362)$ noted that downloading of responsibilities is 'making municipal governments more dependent on local property taxes and more preoccupied with finding ways to strengthen their tax bases'. Yet through provincial legislation, embedded in the Municipal Act, the provincial government maintains considerable control over the municipalities on key financial matters (Arku 2014).

Another potential institutional cause may be linked to the provincial government response to municipal stresses caused by the implementations of neo-liberal policy. In Ontario between 1970 and 2000, provincially mandated amalgamations reduced the number of local municipalities in the province from 815 to 414 (Sancton 2000). The merging of municipalities forced local governments to consider their identities as economies, tangible assets, local histories, and talent pools became merged. Michigan, meanwhile, has embraced neo-liberalism in alternative ways. State law has promoted de facto municipal fragmentation at both inter- and intra-community levels through laws limiting the ability of top-down municipal annexation or consolidation (Jacobs 2009). This may influence a lack of place branding in at least two ways. One way is that less external pressure exists for identifying and promoting a local identity since governments tend to be small. But a second way is that the small size of local governments may make this entrepreneurial activity infeasible economically. As well, further internal divisions may create tension and thus limit the ability to find unifying or cohesive elements that can be incorporated into a local brand (as suggested about general policy direction by Krause 2000).

The institutional climate may additionally have influence on place brand message. Michigan is observed to have a higher rate of industry as a brand within the peripheral municipalities. This might be explained through the free-market political-economic environment that has forced the Michigan municipalities into strong competition for business and industry. Branding message, however, is not guided solely by the political-economic system. In fact, while considerable variation in the messaging of place brands is another reason for dismissing its homogeneity, non-institutional factors may have a greater influence on what municipal elements are being promoted. As noted, place brands tend to gain their messaging from the presentation of local assets and elements to create a sense of place. As such, non-institutional factors such as the local economy, history, and geography play an important role in forming the sense of place of the locale.

Local economy can also be a driving factor in the development of brand messaging. Communities attempting to recruit business may utilize the place brand message to create a 
sense of a productive community with a well-developed industry base. In the recruitment of business and industry, the distribution of assets across the municipalities may play a role. For example, the results of the study show that industry is heavily centred in Ontario's larger urban centre, as a lower proportion of communities (13\% in Ontario; $17 \%$ in Michigan) but higher percentage of the population (29\% in Ontario; $12 \%$ in Michigan) is associated with the industry-based brand. The decline of local economies in Michigan may also be responsible for a generally stronger presence of culture as a place brand category in Michigan as municipalities seek to present non-economic strengths of their communities (Figure 2).

An additional example of the influence of geography is the local physical features available to every community as an asset for presentation, explaining why nature is the most commonly utilized message. Many communities border on one of the Great Lakes, and thus have obvious points of attraction. This is evident in Figure 2, with the nature brand being the most spatially prominent. Physical landscape also explains the variation identified in the level of agriculture-based brands. The geography of southern Ontario has produced ideal soil conditions for agriculture and has historically played an important role in Ontario's economy. As such, the physical conditions that have underpinned this economic sector can be viewed as an important driver of the brand messaging. By comparison, the lower emphasis on agriculture in Michigan (with smaller pockets in the southeast and central western parts of the state) may be due to the presence of more fertile farmland elsewhere in the United States.

\section{Conclusions}

The intention of this paper was to provide a comparative analysis of the presence and nature of place branding as an economic development tool in Michigan and Ontario and serve to shed light on the kinds of messages which are being communicated by municipalities in two neighbouring regions that are located in different national contexts. The study offers insights to practitioners on the dominant themes and patterns in place branding initiatives in the two geographical contexts which may provide a particular value to municipalities that have not yet adopted place branding but who are considering the practice. Additionally, the results serve as a hypothesis generator for future research. Of importance is the as yet unknown effectiveness of these place branding strategies in enhancing the development of the two regions. Given geographic similarities among certain place brands, we posit that some opportunity exists for municipalities to brainstorm collaborative strategies and therefore capitalize on existing resources. As well, given that economic development practice tends to be evolutionary, a temporal analysis of place brands could help identify changes of the nature and extent of place branding over time. Comparing these changes to improvements in local economic conditions could yield evidence in support of the use of place branding.

This article has taken the first step in identifying rates and patterns in place branding activities with the use of images and symbols. By combining this information with measures of economic success, economic policymakers may use this information to determine the relative benefits of the use or lack of place branding in Michigan and Ontario. Future research could also explore some of the lingering questions from a qualitative lens to gain a better understanding of the intricacies involved in place branding initiatives. For instance, interviews with practitioners might help to unpack the reasons behind place brand designs and strategic goals, the definition of logos and slogans, and the specific target audiences for place brand messages. Such work would give added value to policymakers and researchers interested in understanding this entrepreneurial activity. 


\section{Acknowledgements}

The authors wish to thank the two anonymous reviewers for their helpful comments on an earlier draft. None bear any responsibility for the arguments presented here. Finally, the authors wish to thank the three research assistants: Haider Khalil, Nada Elhayek and Salman Siddiqui. Your time and effort throughout the project are greatly appreciated.

\section{Disclosure statement}

No potential conflict of interest was reported by the authors.

\section{References}

Addie, J.-P. D. 2008. "The Rhetoric and Reality of Urban Policy in the Neoliberal City: Implications for Social Struggle in Over-The-Rhine, Cincinnati." Environment and Planning A 40: 2674-2692. doi:10.1068/a4045.

Allen, G. 2007. "Place Branding: New Tools for Economic Development." Design Management Review 18: 60-68. doi:10.1111/j.1948-7169.2007.tb00084.x.

Arku, G. 2013. "Outsourcing Functions to Economic Development Corporations: Exploring the Perceptions of Officials in Ontario, Canada." Public Organization Review 13 (1): 49-70. doi:10.1007/s11115-012-0193-8.

Arku, G. 2014. "Competition and Cooperation in Economic Development: Examining the Perceptions of Practitioners in Ontario, Canada." Canada. Journal of Urban Affairs 36: 99-118. doi:10.1111/j.1467-9906.2012.00647.x.

Arku, G., and C. Oosterbaan. 2014. "Evidence of Inter-Territorial Collaborative Economic Development Strategies in Ontario, Canada." GeoJournal. doi:10.1007/s10708-014-9554-x.

Askegaard, S. 2006. "Brands as a Global Ideoscape." In Brand Culture, edited by J. Schroder and M. Salzer-Morling, 91-102. London: Routledge.

Avraham, E. 2004. "Media Strategies for Improving an Unfavorable City Image." Cities 21 (6): 471-479.

Barke, M. 1999. "City Marketing as a Planning Tool." In Applied Geography: Principles and Practice, edited by M. Pacione, 486-496. London: Routledge.

Barke, M., and K. Harrop. 1994. "Selling the Industrial Town: Identity, Image and Illusion." In Place Promotion: The Use of Publicity and Marketing to Sell Towns and Regions, edited by J. R. Gold and S. V. Ward, 93-114. Chichester: John Wiley \& Sons.

Brenner, N., and N. Theodore. 2002. "Cities and the Geographies of Actually Existing Neoliberalism." In Spaces of Neoliberalism: Urban Restructuring in North America and Western Europe, edited by N. Brenner and N. Theodore, 2-32. Oxford: Blackwell.

Buss, T. 2001. "The Effect of State Tax Incentives on Economic Growth and Firm Location Decisions: An Overview of the Literature." Economic Development Quarterly 15: 90-105. doi: $10.1177 / 089124240101500108$.

Cleave, E., and G. Arku. 2014. "Place Branding and Economic Development at the Community Level in Ontario, Canada." GeoJournal. doi:10.1007/s10708-014-9554-x.

Cova, B. 1996. "The Postmodern Explained to Managers: Implications for Marketing." Business Horizons 39: 15-23. doi:10.1016/S0007-6813(96)90032-4.

Danesi, M. 2006. Brands. New York: Routledge.

Dewar, M. E. 1998. "Why State and Local Economic Development Programs Cause so Little Economic Development." Economic Development Quarterly 12: 68-87. doi:10.1177/ 089124249801200106.

Dinnie, K. 2011. City Branding: Theory and Cases. Basingstoke: Palgrave Macmillan.

Eisenschitz, A. 2010. "Neo-Liberalism and the Future of Place Marketing." Place Branding and Public Diplomacy 6: 79-86. doi:10.1057/pb.2010.12.

Eshuis, J., and A. Edwards. 2012. "Branding the City: The Democratic Legitimacy of a New Mode of Governance." Urban Studies 50 (5): 1066-1082.

Gerber, E. R., and C. G. Loh. 2010. "Prospects for Expanding Regional Planning Efforts in Michigan." Urban Studies 48: 2303-2319. doi:10.1177/0042098010380959.

Gertler, M. S. 1990. "Economic Development." In Urban Policy Issues: Canadian Perspectives, edited by. R. A. Loreto and T. Price, 33-57. Toronto, ON: McClelland and Stewart. 
Gertner, D. 2011. "Unfolding and Configuring Two Decades of Research and Publications on Place Marketing and Place Branding." Place Branding and Public Diplomacy 7: 91-106. doi:10.1057/pb.2011.7.

Gillen, J. 2009. "The Co-Production of Narrative in an Entrepreneurial City: An Analysis of Cincinnati, Ohio, in Turmoil." Geografiska Annaler Series B: Human Geography 91: 107-122. doi:10.1111/j.1468-0467.2009.00309.x.

Giovanardi, M. 2012. "Haft and Sord Factors in Place Branding: Between Functionalism and Representationalism." Place Branding and Public Diplomacy 8 (1): 30-45. doi:10.1057/ pb.2012.1.

Greenberg, M. A. 2008. Branding New York. How a City in Crisis Was Sold to the World. London: Routledge.

Hackworth, J. 2007. The Neoliberal City: Governance, Ideology, and Development in American Urbanism. New York: Cornell University Press.

Hanna, S., and J. Rowley. 2008. "An Analysis of Terminology Use in Place Branding." Place Branding and Public Diplomacy 4 (1): 61-75. doi:10.1057/palgrave.pb.6000084.

Hanna, S., and J. Rowley. 2013. "Place Brand Practitioners' Perspectives on the Management and Evaluation of the Brand Experience.” Town Planning Review 84: 495-515. doi:10.3828/ tpr.2013.25.

Hannigan, J. 2003. "Symposium on Branding, the Entertainment Economy and Urban Place Building: Introduction." International Journal of Urban and Regional Research 27: 352-360. doi:10.1111/ijur.2003.27.issue-2.

Hansen, R. H. 2010. "The Narrative Nature of Place Branding." Place Branding and Public Diplomacy 6: 268-279. doi:10.1057/pb.2010.27.

Harvey, D. 1989. "From Managerialism to Entrepreneurialism: The Transformation in Urban Governance in Late Capitalism." Geografiska Annaler Series B, Human Geography 71: 3-17.

Harvey, D. 2007. "Neoliberalism as Creative Destruction." The Annals of the American Academy of Political and Social Science 610: 21-44. doi:10.1177/0002716206296780.

Harvey, J., and R. Young. 2012. Image-building in Canadian Municipalities. Kingston: McGillQueen's University Press.

Hislop, M. 2001. "Branding 101: An Overview of Branding and Brand Measurements for Online Marketers." Dynamic Logic. http://www.studymode.com/essays/ Branding -170582.html.

Hubbard, P., and T. Hall. 1998. "The Entrepreneurial City and the New Urban Politics." In The Entrepreneurial City: Geographies of Politics, Regime and Representation, edited by T. Hall and P. Hubbard. Chichester: John Wiley \& Sons.

Hutton, T. 2010. Economic Change in Canadian Cities: Locational Dynamics of Employment. In Canadian Cities in Transition: New Directions in the Twenty-First Century, edited by T. Bunting, P. Filion, and R. Walker, 110-130. Oxford: Oxford University Press.

Jacobs, A. J. 2009. "The Impacts of Variations in Development Context on Employment Growth: A Comparison of Central Cities in Michigan and Ontario, 1980-2006." Economic Development Quarterly 23: 351-371. doi:10.1177/0891242409343304.

Johansson, M. 2012. "Place Branding and the Imaginary: The Politics of Re-imagining a Garden City." Urban Studies 49: 3611-3626. doi:10.1177/0042098012446991.

Kavaratzis, M. 2009. "Cities and Their Brands: Lessons from Corporate Branding." Place Branding and Public Diplomacy 5: 26-37. doi:10.1057/pb.2008.3.

Khirfan, L., and B. Momani. 2013. "(Re)Branding Amman: A 'Lived' City's Values, Image and Identity." Place Branding and Public Diplomacy 9: 49-65. doi:10.1057/pb.2013.1.

Kim, C. 2010. "Place Promotion and Symbolic Characterization of New Songdo City, South Korea." Cities 27: 13-19. doi:10.1016/j.cities.2009.11.013.

Kolesar, A. 1990. "Can State and Local Tax Incentives and Other Contributions Stimulate Economic Development." The Tax Lawyer 44: 285-311.

Krause, G. A. 2000. "Partisan and Ideological Sources of Fiscal Deficits in the United States." American Journal of Political Science 44 (3): 541-559.

Ladd, H. F. 1994. "Spatially Targeted Economic Development Strategies: Do They Work?" Cityscape 1: 193-208.

Leigh, N. G., and E. J. Blakely. 2013. Planning Local Economic Development: Theory and Practice. Thousand Oaks, CA: Sage. 
Lucarelli, A., and P. O. Berg. 2011. "City Branding: A State-Of-The-Art-Review of the Research Domain." Journal of Place Management and Development 4: 9-27. doi:10.1108/ 17538331111117133.

Marling, G., O. B. Jensen, and H. Kiib. 2009. "The Experience City: Planning of Hybrid Cultural Projects." European Planning Studies 17: 863-885. doi:10.1080/09654310902794018.

Martínez, J. G. 2007. "Selling Avant-Garde: How Antwerp Became a Fashion Capital (19902002)." Urban Studies 44: 2449-2464. doi:10.1080/00420980701540879.

Millington, S., C. Young, and J. Lever. 1997. "A Bibliography of City Marketing.” Journal of Regional and Local Studies 17: 16-42.

Niedomysl, T. 2004. "Evaluating the Effects of Place-Marketing Campaigns on Interregional Migration in Sweden." Environment \& Planning A 36: 1991-2009. doi:10.1068/a36210.

Niedomysl, T. 2007. "Promoting Rural Municipalities to Attract New Residents: An Evaluation of the Effects." Geoforum 38: 698-709. doi:10.1016/j.geoforum.2006.11.024.

Pasquinelli, C. 2013. "Competition, Cooperation and Co-Opetition: Unfolding the Process of InterTerritorial Branding." Urban Research \& Practice 6: 1-18. doi:10.1080/ 17535069.2012.727579.

Peck, J. 2002. "Political Economies of Scale: Fast Policy, Interscalar Relations, and Neoliberal Workfare." Economic Geography 78: 331-360.

Rantisi, N. M., and D. Leslie. 2006. "Branding the Design Metropole: The Case of Montrèal, Canada." Area 38: 364-376. doi:10.1111/area.2006.38.issue-4.

Reese, L. 1992a. "Explaining the Extent of Local Economic Development Activity: Evidence from Canadian Cities." Environment and Planning C 10 (1): 105-120.

Reese, L. A. 1992b. "Local Economic Development in Michigan: A Reliance on the Supply Side." Economic Development Quarterly 6: 383-393. doi:10.1177/089124249200600404.

Reese, L. A. 1993. "Local Economic Development Practices across the Northern Border." Urban Affairs Review 28: 571-592. doi:10.1177/004208169302800404.

Reese, L. A. 2010. "The State of Canadian Cities: Theoretical and Applied Themes: An Introduction." GeoJournal 75: 509-516. doi:10.1007/s10708-009-9274-9.

Reese, L. A. 2014. Local Economic Development Policy. The United States and Canada. New York: Routledge.

Reese, L. A., and A. Malmer. 1994. "The Effects of State Enabling Legislation on Local Economic Development Policies." Urban Affairs Review 30: 114-135. doi:10.1177/004208169403000106.

Reese, L. A., and G. Sands. 2007. "Making the Least of Our Differences? Trends in Local Economic Development in Ontario and Michigan, 1990-2005." Canadian Public Administration 50: 79-99. doi:10.1111/capa.2007.50.issue-1.

Rubin, I. S., and H. J. Rubin. 1987. "Economic Development Incentives: The Poor (Cities) Pay More." Urban Affairs Review 23: 37-62. doi:10.1177/004208168702300104.

Sadler, R. C., M. Clark, and J. Gilliland. 2013. "An Economic Impact Comparative Analysis of Farmers' Markets in Michigan and Ontario." Journal of Agriculture Food Systems and Community Development 3: 61-81. doi:10.5304/jafscd.2013.033.009.

Sancton, A. 2000. "Amalgamations, Service Realignment, and Property Taxes: Did the Harris Government Have a Plan for Ontario's Municipalities?" Canadian Journal of Regional Science 23: 135-156.

Tiebout, C. 1956. "A Pure Theory of Local Expenditures." The Journal of Political Economy 64: 416-424.

Turok, I. 2009. "The Distinctive City: Pitfalls in the Pursuit of Differential Advantage." Environment and Planning A 41: 13-30. doi:10.1068/a37379.

Urban, F. 2002. "Small Town, Big Website?: Cities and their Representation on the Internet." Cities 19: 49-59. doi:10.1016/S0264-2751(01)00045-2.

Wolfe, D. A., and M. S. Gertler. 2001. "Globalization and Economic Restructuring in Ontario: From Industrial Heartland To Learning Region?" European Planning Studies 9: 575-592. doi:10.1080/09654310124479.

Wolfson, J., and F. Frisken. 2000. "Local Response to the Global Challenge: Comparing Local Economic Development Policies in a Regional Context." Journal of Urban Affairs 22: 361-384. doi:10.1111/juaf.2000.22.issue-4.

Zukin, S. 1989. Loft Living: Culture and Capital in Urban Change. New Brunswick, NJ: Rutgers University Press. 